Global Conferences Series:

Social Sciences, Education and Humanities (GCSSSEH), Volume 3, 2019

The $1^{\text {st }}$ International Conference on Education, Social Sciences and Humanities

DOI: https://doi.org/10.326/hum0213

\title{
Evaluation of Teacher Professional Training Program with Contextual, Input, Process, and Product (CIPP) Models
}

\author{
Muhammad Bukhori Dalimunthe ${ }^{1(*)}$, Eko Wahyu Nugrahadi ${ }^{2}$, Fitrawaty ${ }^{3}$, Raudah \\ Zaimah Dalimunthe ${ }^{4}$ \\ 1,2,3 Universitas Negeri Medan, Medan, Indonesia \\ ${ }^{4}$ Universitas Sultan Ageng Tirtayasa, Serang, Indonesia \\ $\left.{ }^{*}\right) \bowtie \underline{\text { daliori86@unimed.ac.id }}$
}

\begin{abstract}
The research objective is to evaluate the teacher professional training (TPT) programs using context, input, process, and product (CIPP) models. 80 teachers who had completed the TPT programs in Faculty of Economics, Universitas Negeri Medan, participated as the respondents. The researchers collecting the data using survey-based questionnaire and analyze it using descriptive statistics. The results of this evaluation study indicate the dominant aspects of the implementation of TPT programs as follows (1) Context aspect shows that TPT programs are useful in teacher professional development; (2) Input aspect shows that schools are qualified and cooperative in implementing field experience in the sub of TPT programs; (3) Process aspect shows that material content of performance tests are relevant to the criteria of teacher on pedagogical and professional competence; and (4) product aspect shows that the TPT programs affect changes in teaching methods in schools.
\end{abstract}

Keywords: Evaluation, Teacher Professional Training Programs.

\section{Introduction}

To realize the development of quality in human resources, it is necessary to strengthen fundamental and comprehensive education. The government is fully responsible for this. Therefore, Government Regulation number 74 of 2008 concerning the Teacher has been issued. The regulation is the basis of teacher reform in Indonesia where teachers must be prepared through professional education after a bachelor program called teacher professional training (TPT).

The implementation of the TPT program is in line with the National Qualifications Framework (in Indonesia knows as Kerangka Kualifikasi Nasional Indonesia or KKNI) so that Universities are obliged to prepare competent and superior teachers in the face of the digital era revolution. Universitas Negeri Medan is one of 10 universities in Indonesia that have two direct mandates in the implementation of the TPT program, namely the pre-office TPT and In-Office TPT program through Minister of Research, Technology and Higher Education Regulation number 280 in 2017.

The mandate was carried out by the Faculty of Economics, Universitas Negeri Medan by preparing all resources to provide optimal services to TPT program participants. In order to support the sustainability of the TPT program, it is necessary to evaluate the implementation of the TPT

Copyright $@$ ( 2019, the Authors. Published by Redwhite Press.

Page | 168

This is an open access article under the CC BY-NC license

(http://creativecommons.org/licenses/by-nc/4.0). 
program that has been completed, so that the weaknesses and advantages of the TPT program can be followed up to improve teacher competency.

Evaluation has a different meaning from assessment, measurement, or test. Stufflebeam and Shinkfield (1985) state that evaluation is a process of providing information that can be used as a consideration for the goals to be achieved, design, implementation and impact on helping decision making, assist accountability and improve understanding of phenomena. Whereas, Brinkerhoff et al. (1986) explained that evaluation is a process that determines the extent to which educational goals can be achieved. Based on several theories, evaluation interpreted as a systematic and continuous process in collecting, describing, interpreting and presenting information that can be used as a basis for decision making, formulating policies and developing following programs..

The purpose of this study is to evaluate the TPT program using the CIPP model; this is because the teachers are transformed using technology in increasing competence. The TPT program is the most up-to-date, comprehensive teacher competency improvement program with the challenges of the digital era revolution. The TPT program adopts the Blended Learning approach, so the TPT program participants start the learning process through an online, workshop, then Field Learning Program, and ends with a performance exam. The TPT program assessment system is so comprehensive taking into account the results of online learning, written examinations, and performance examinations. These various things make this evaluation research interesting to study using the CIPP model approach.

\section{Method}

This research is survey research to reveal respondents about evaluating the implementation of the TPT program. Data collection uses closed instruments distributed to respondents through the help of google form. The development of survey instruments refers to the indicators contained in the TPT Guidelines, issued by the Directorate General of Learning and Student Affairs. Instruments that have been determined by indicators have collaborated with the concept of evaluating the context, input, process, and product (CIPP) models developed by Stufflebeam (1983).

The instrument is presented with five choices of Likert scale answers. Before being used to collect questionnaire data, the content validity test was carried out with expert judgment and empirical validity, and reliability with a pilot test. So the questionnaire is valid and reliable in explaining the phenomenon in the field. The instrument was then designed into the Google Form so that it could be easily accessed by TPT program alumni who had returned to their respective work areas. After being designed and uploaded into an electronic instrument with the Google Form facility, the instrument was sent by e-mail to the respondents and carried out a notification via short message to the cellphone and e-mail of each respondent..

The research sample is the teachers of the education study program who have completed the TPT program from the Faculty of Economics, Universitas Negeri Medan in 2018. A total of 80 teachers who have completed the TPT program fill in the research instruments. The data analysis technique uses descriptive statistics.

\section{Results and Discussion}

Based on the data that has been collected, then the demographic data of the research sample are presented in Table 1.

Table 1. Sample demographics

\begin{tabular}{|c|c|c|c|c|c|}
\hline \multicolumn{2}{|c|}{ Gender } & \multicolumn{2}{|c|}{ Educational level } & \multicolumn{2}{|c|}{ Marital Status } \\
\hline Male & Female & Bachelor & Master & Married & Unmarried \\
\hline
\end{tabular}


17
63

73
73

Overall, 80 teachers who completed the TPT program consisted of 63 women and 17 men. The majority of the education is bachelor with a total of 73 , while 7 other teachers have master's degrees. Furthermore, marital status is dominated by married status of 73 teachers while 7 other teachers are unmarried.

After data collecting on perceptions of teachers who have completed the TPT program has finished, the next step is to tabulate the data. The results of the subsequent data tabulation were explored in depth by conducting a Focus Group Discussion (FGD) with experts. Experts in this study were all study program chairpersons of TPT program organizers, representatives of pedagogical and professional lecturers, vice deans, and deans. The FGD was conducted to sharpen the evaluation on the parts of the content, practice, and strategy of implementing the TPT program so that the evaluation results became recommendations for improving the quality of the TPT program implementation for the next period.

\section{The Response of TPT Program Participants Regarding Context}

The context aspect describes the urgency and relevance of the TPT program in the development of teacher professionalism. In this section, the researcher observes from the teacher as an education practitioner who acts directly in teaching and learning activities in the classroom. From the survey results, it was found that $90.75 \%$ of respondents' scores indicated that the TPT program that had been experienced was useful in self-professional development.

Based on the response, it is known that the objectives of TPT implementation are following the teacher's expectations in his professional development. The TPT program is mainly aimed at improving the quality of teachers and has arrived at a view that is in line with the expectations of teachers in improving their capacity and performance. In a managerial context, the phenomenon shows that teachers and policymakers, in this case, the government, have had goal congruence in teacher development programs framed in the TPT program. Interestingly, from these results, there were $17 \%$ of the response scores of TPT alumni who were of the view that the TPT program was not relevant in overcoming the problems of teacher learning practices. This value is indeed relatively small but indicates a slight gap between the implementation of the TPT program and the problem of teacher learning in schools.

Table 2. TPT Program Evaluation from Contextual Aspects

\begin{tabular}{clc}
\hline No. & \multicolumn{1}{c}{ Question item } & Scores \\
\cline { 2 - 3 } & Context Aspects & 90.00 \\
\hline 1 & TPT Program Needs in teacher professional development. & 90.75 \\
\hline 2 & Use of the TPT Program in the educator professional development. & 83.00 \\
\hline 3 & $\begin{array}{l}\text { The relevance of the TPT Program in overcoming the problems of teacher } \\
\text { learning practices. }\end{array}$ & \\
\hline
\end{tabular}

\section{The Response of TPT Program Participants Regarding Input}

Analysis related to TPT activity inputs discussed the readiness of all aspects that were in contact with the implementation of TPT. These aspects are: 1) Participants; 2) Lecturers; 3) Staff Teacher; 4) Campus and School Infrastructure; 5) Curriculum; 6) Modules; 7) Partner Institutions; 8) Evaluation Tool. From the aspect of participant criteria, more than $80 \%$ of the response scores indicated that participants viewed the criteria set for prospective TPT participants as being in line with the qualifications of prospective professional teachers. For this aspect, the criteria for prospective participants are determined by the Ministry of Education which is standardized in the Minister of Education Regulation No. 37 of 2017. So that all TPT implementing institutions are subject to these regulations and proposals for each prospective participant refer to these regulations. So that the teacher's perception can be seen as support and understanding of the regulation. 
Furthermore, more than $80 \%$ of the response scores of TPT program participants were of the view that tutors and mentor teacher had adequate qualifications in presenting TPT materials and assisting TPT participants in developing professional and pedagogic competencies. This situation shows that the qualifications of appointed lecturers and tutors are following the competency requirements and expectations of TPT participants. However, there are around $10 \%$ of the responses that deserve attention because they show that there are still competency gaps between the tutors and mentor teacher. Specific identification related to these aspects can be a policy recommendation in the selection of TPT lecturers and teachers.

In terms of curriculum relevance and content in the module with the latest educational problems and educational problems in each school, participants had a response score of $80 \%$. The response indicates that the curriculum and material discussed in the TPT program have functional relevance to global strategic issues and actual problems in schools. However, there are limitations to the implementation of competencies obtained from the TPT program. The limitations of the implementation occur because the curriculum content in the TPT program is futuristic and seeks to respond to the digital age challenge. While specific problems differ in each of the schools in Indonesia so that in this aspect the effort to respond to the digital age in some schools in Indonesia is still difficult to do as a whole due to limited infrastructure, student characteristics, and organizational dynamics in the area of origin.

Furthermore, the participants gave the biggest response with a score of $92.5 \%$ related to partner school cooperation in the implementation of Student field experience programs. This condition is perfect for institutions and participants because it shows the adequacy of synergy between the Faculty of Economics and stakeholders to improve the quality of education. Cooperation and collaboration between educational institutions are vital because improving the quality of education must run systemically. Because there are so many elements involved in the implementation of education ranging from the central policy level, regional policies, higher education policies to produce teachers, school policies, teacher professional association policies, to the policy of implementing classroom learning.

Finally, in terms of monitoring and evaluation alumni view that this is very necessary, especially in the evaluation of instructors and teaching modules. Responses related to this show a $90 \%$ perception score on instructor evaluation, $88 \%$ response score in the module, and $79.25 \%$ response score in the organizer's study program. This perception was accommodated by a survey related to the implementation of instructor evaluations by TPT program participants; more than $80 \%$ of participants revealed that participants filled out the instructor evaluation form. However, the evaluation of the module and the organizer's study program have not been conducted.

Tabel 3. TPT Program Evaluation of Input Aspects

\begin{tabular}{clc}
\hline \multirow{2}{*}{ No. } & \multicolumn{1}{c}{ Question item } & $\begin{array}{c}\text { Scores } \\
\text { (\%) }\end{array}$ \\
\cline { 2 - 3 } & Input Aspects & 85.75 \\
& $\begin{array}{l}\text { Compliance with the criteria for TPT program participants with the } \\
\text { qualifications of professional teacher candidates }\end{array}$ & 85.06 \\
\hline 2 & $\begin{array}{l}\text { Competence of TPT program participants in participating in TPT learning } \\
\text { program }\end{array}$ & 88.00 \\
\hline 3 & Lecturer competency in presenting material in the TPT program & 87.25 \\
\hline 4 & $\begin{array}{l}\text { Teacher mentor competency in assisting TPT participants in implementing } \\
\text { Student Field Experience }\end{array}$ & 81.75 \\
\hline 5 & The available learning facilities support the implementation of the TPT program \\
\hline 6 & Topics available in the TPT curriculum is in line with the needs of the teacher & 83.75 \\
\hline 7 & Topics available in the TPT curriculum help in solving teaching problems & 86.25 \\
\hline 8 & Available modules help in achieving learning goals at each topic & 83.75 \\
\hline
\end{tabular}




\begin{tabular}{clc}
\hline 9 & $\begin{array}{l}\text { Cooperative partner institutions (schools) in implementing Student Field } \\
\text { Experience }\end{array}$ & 92.50 \\
\hline 10 & $\begin{array}{l}\text { Competencies obtained in workshops (face-to-face learning) can be applied to } \\
\text { partner institutions (schools) }\end{array}$ & 89.25 \\
\hline 11 & $\begin{array}{l}\text { Academic regulations in the implementation of TPT help organize the Student } \\
\text { Field Experience program }\end{array}$ & 84.00 \\
\hline 12 & The organizational structure of TPT organizers is well & 80.00 \\
\hline 13 & \begin{tabular}{l} 
Instructor evaluation by TPT participants needs to be done at the end of each \\
\multicolumn{1}{l}{ Student Field Experience workshop }
\end{tabular} & 90.00 \\
\hline 14 & Module evaluation needs to be done by TPT participants & 88.00 \\
\hline 15 & Monitoring and evaluating the preparation of TPT organizer study programs & 79.25 \\
\hline
\end{tabular}

\section{The Response of TPT Program Participants Regarding Process}

Evaluation in the process aspect refers to 1) the institutional management of TPT providers; 2) learning process; 3) learning material; 4) implementation of Student Field Experience; 5) implementation of written examinations and performance tests. In general, responses from TPT participants produced scores above $80 \%$ except for content that discussed the relevance of the material presented in modules and workshops with the material tested in written tests; this content received a response score of less than $80 \%$ even though it still had a response score above $70 \%$. This indicates that the management of the TPT program by the Faculty of Economics, the implementation of classroom learning by lecturers, and mentoring by partner schools has gone well. However, there is a slight gap between the module material and the implementation of learning with the questions tested in the written exam. The gap does not seem to be far apart. However, the Faculty of Economics as an organizer deserves attention and further evaluates the gap between the questions and teaching materials by relying on the learning objectives and achievements of the TPT program. This needs to be done to control all learning activities the TPT program is maintained in the corridors of the objectives and learning outcomes set, both teaching material, practice material, and written test material and performance examinations.

Table 4. TPT Program Evaluation of Process Aspects

\begin{tabular}{llc}
\hline No. & \multicolumn{1}{c}{ Question item } & $\begin{array}{c}\text { Scores } \\
\text { (\%) }\end{array}$ \\
\cline { 2 - 3 } & Process Aspects & 80.25 \\
\hline 1 & $\begin{array}{l}\text { The institutional management of TPT organizers' study programs has been } \\
\text { well done }\end{array}$ & 81.50 \\
\hline 2 & Monitoring and evaluation of learning in the TPT program has been well done & 82.53 \\
\hline 3 & $\begin{array}{l}\text { The workshop learning process in the TPT program helps participants in } \\
\text { written tests and performance tests }\end{array}$ & 85.25 \\
\hline 4 & $\begin{array}{l}\text { Workshop learning material in the TPT program is relevant to the material } \\
\text { tested in the written test and performance test }\end{array}$ & 88.50 \\
\hline 5 & $\begin{array}{l}\text { The process of Student Field Experience learning in the TPT program has been } \\
\text { well done }\end{array}$ & $\begin{array}{l}\text { Aspects assessed in the performance test are in line with the criteria of } \\
\text { pedagogical and professional teacher competence }\end{array}$ \\
\hline 7 & $\begin{array}{l}\text { The material tested in the local writing test on the TPT program is in line with } \\
\text { the material of pedagogical and professional competencies obtained in } \\
\text { modules and workshops }\end{array}$ & 80.75 \\
\hline 8 & $\begin{array}{l}\text { The material tested in the national written test on the TPT program is in line } \\
\text { with the criteria for pedagogical and professional competence obtained in }\end{array}$ & 77.50 \\
\hline
\end{tabular}

The Response of TPT Program Participants Regarding Products 
Product evaluation wants to ensure that the teacher development program aimed at the TPT program is to answer the problem of practical education for teachers and schools in Indonesia to support national education goals. The key indicators of practical problem-solving in school learning related to teacher development training are the relevance of training material to the problems faced by teachers in the classroom. Therefore, product evaluation is extracted into two key aspects, namely 1) the usefulness of competencies obtained in changing teacher teaching methods; and 2) the applicative power of competencies obtained in the implementation of learning in the original school.

The response score obtained is more than $80 \%$ for both aspects. In general, respondents felt that the competencies obtained from the TPT program brought change to the way to teach teachers in the classroom and implement it in their schools. This situation means that the competencies obtained are relevant to the strategic needs of the school so that they can be applied practically in learning activities to teach teachers in their original schools.

Table 5. TPT Program Evaluation of Product Aspects

\begin{tabular}{clc}
\hline \multirow{2}{*}{ No. } & \multicolumn{1}{c}{ Question item } & \multirow{2}{*}{ Scores \% } \\
\cline { 2 - 3 } & Product Aspects & 88.25 \\
\hline 1 & $\begin{array}{l}\text { How much influence does the TPT program have on changing how you teach } \\
\text { at school? }\end{array}$ & 86.50 \\
\hline 2 & $\begin{array}{l}\text { How applicable are the competencies obtained from the TPT program in } \\
\text { implementing learning in your school? }\end{array}$ & \\
\hline
\end{tabular}

\section{Conclusions}

Based on the research findings, this study formulates the following conclusions:

1. In the context aspect, the implementation of the TPT program is in line with the context of the practical problems faced by teachers in schools. So that teachers can see that the TPT program is an effort to develop teacher capacity which in turn will give teachers new competencies to improve the quality of learning in the classroom.

2. In the input aspect, the role of the teacher as the respondent and the Faculty of Economics as the organizer considers that the TPT program input criteria have standardized qualifications. Because indeed the input criteria have been regulated in a standard and standard manner at the Minister of National Education No. 37 of 2017. So that it can be understood that the government has guaranteed the standard input of both participants, instructors, officials, curriculum and teaching materials, campus and school infrastructure.

3. In the process aspect, the implementation of the TPT program has been going well. Campus infrastructure is adequate with comfortable classrooms and sufficient internet network, qualified lecturers who have good competence and mastery of material, modules that are available and have high accessibility, and cooperative partner schools. However, there is a slight decrease in scores on the sub-aspects of the relevance of the material taught and the material in the module with written exam material experienced by alumni. This finding is expected to be explored further by referring to the learning objectives and achievements of the TPT program.

4. In the product aspect, the implementation of the TPT program has fulfilled the teacher's expectations with the competencies obtained by the teacher can be implemented in the original school, thus helping teachers to make changes to classroom learning. However, some limitations to implementation continue to occur due to gaps in student characteristics, school infrastructure readiness, and social conditions in schools. This aspect certainly can be a new input for organizers to continually enrich and update training materials so that they can bridge the gaps in the implementation of competencies in the field. 


\section{Acknowledgments}

The research was funded by Universitas Negeri medan through a research grant. The research team are grateful to all respondents and interested parties at the Faculty of Economics who had helped.

\section{References}

Brinkerhoff, R. O. et. al. (1986). Program Evaluation: A Practitioner's Guide for Trainers and Educators. Fourth Printing. Massachusetts: Kluwer-Nijhoff Publishing.

Keputusan Menteri Riset, Teknologi, dan Pendidikan Tinggi nomor 280 tahun 2017 tentang Perguruan Tinggi Penyelenggaraan Program Pendidikan Profesi Guru.

Peraturan Pemerintah Republik Indonesian nomor 74 tahun 2008 tentang Guru.

Stufflebeam, D.L. (1983) The CIPP Model for Program Evaluation. In: Evaluation Models. Evaluation in Education and Human Services, vol 6. Springer, Dordrecht.

Stufflebeam, D.L. and Shinkfield, A.J. (1985). Systematic Evaluation: A Self-Instructional Guide to Theory and Practice. Massachusetts: Kluwer-Nijhoff Publishing. 